\title{
PENYEDIAAN AIR UNTUK KEPERLUAN DOMESTIK DI DAERAH PEDESAAN SEKITAR PHNOM PENH KAMBOJA
}

\author{
Oieb : Sudarmadji
}

\section{ABSTRACT}

Domestic water supply and sanitation are essential needs for people in the rural area, nevertbeless they are still problems in the developing countries. This situation were observed in the rural areas of the developing countries, one among them was observed in Cambodia. Beside the country is classified as a developing country, at the present Cambodia is suffering from the long period of war. Water supply system which was observed in Khum Viley, Kompisei District, The Province of Kompong Speau is an example of the rural water supply and sanitation system. Water is obtained from rain water, surface water (rivers, and ponds) and groundwater. Water is collected using simple way, even ignoring bealth aspect of the community. Water which is withdrawn from natural water body like swamps and ponds, is stored in the traditional storage tanks before it is used, especially those for drinking and cooking.

To improve the individual water supply system facilities the technology (eventhough the simple one) and the socio economic of the population are the factors sbould be taken into account. Long periods of war bas a significant impact on the socio economic of the people in Cambodia. People bave no opportunity to think of improving the water supply facilities due to the unfovourable situation. This situation has brought the people in a such condition that they mostly used water naturally witbout taking into account the quality and ignoring the bealth aspects. Tbis situation has to be recognised if the water supply facilities in the rural area of the country would be improved.

\section{INTISARI}

Air bersib dan sanitasi merupakan kebutuban utama penduduk, namun bal tersebut masib merupakan masalab yang pelik di daerab-daerab pedesaan negara-negara Kamboja. Selain termasuk negara berkembang, saat ini negara itu masib dalam situasi pasca perang yang berkepanjangan. Penyediaan air yang teramati di daerah pedesaan sekitar Khum Vilei, Distrik Kompisei, Propinsi Kompong Speau, merupakan salab satu contob penyediaan air bersib dan sanitasi bagi masyarakat di daerab pedesaan yang perlu mendapat perbatian. Sumber air sntuk keperiuan domestik diperoleb dari berbagai sumber, yaitu dari air bujan, air persmukaan (sungai, rawa dan genangan alau kolam), dan air tanab. Air untuk keperluan domestik diperoleb dengan teknik sederbana, babkan kadang-kadang memperbatikan aspek kesebatan masyarakat. Air tersebut didapatkan dari 
air bujan, air permukaan dan air tanab. Sebelum digunakan (kbususnya untuk masak dan minum) ditampung dan disimpan dahulu dengan tempayan khas daerab yang bersangkutan.

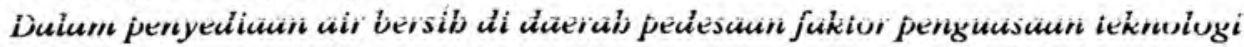
dan dana yang dimiliki penduduk setempat sangat menentukan. Perang yang berkepanjangan mengakibatkan kondisi sosial ekonomi masyarakat pedesaan sangat mempribatinkan, sebingga tidak sempat memikirkan perbaikan sarana sanitasi dan masalab yang berkailan dengan penyediaan air bersib. Hal ini membawa kepada situasi dimana penduduk menggunakan air apa adanya tanpa memperhatikan kualitasnya, dan sering tanpa memikirkan aspek kesebatan. Hal ini harus diperbatikan dalam melakukan perbaikan dan pengadaan sarana air ber. sib dan sanitasi di daerab pedesaan negara tersebut.

\section{PENDAHULUAN}

Di daerah-daerah pedesaan di negara-negara berkembang air bersih dan sanitasi masih merupakan masalah yang serius yang perlu mendapatkan perhatian. Penyediaan maupun sumber air bersih yang digunakan sangat bervariasi dari daerah satu ke daerah lain. Sumber air tersebut bervariasi dari air hujan, air permukaan (sungai, danau, rawa) maupun air tanah. Ketersediaan air di daerah yang bersangkutan berpengaruh terhadap cara maupun teknik penyediaannya. Seringkali cara-cara penyediaan air yang sederhana dilakukan untuk mendapatkan air, bahkan seringkali cara-cara yang sederhana itu mengabaikan aspek-aspek kesehatan. Pengamatan lapangan di daerah-daerah sekitar Phonm Penh, Kamboja dapat digunakan sebagai salah satu gambaran cara penyediaan air di daerah di negara berkembang, khususnya negara Kamboja.

Negara Kamboja yang dilanda perang saudara yang berkepanjangan jangan sampai saat ini belum sempat membangun negara, termasuk saranasarana air bersih, drainase dan sistem transportasi, walaupun hal tersebut sangat diperlukan. Survai selama tujuh hari oleh Penulis bersama Tim Bantuan Teknik RI kepada Kamboja dapat memberikan gambaran sistem penyediaan air bersih di daerah sekitar Phnom Penh, khususnya di daerah-daerah pedesaan. Walaupun survei tersebut dilakukan dalam waktu singkat dapat mengidentifikasikan masalah-masalah yang berkaitan dengan penyediaạn air bersih dan sanitasi, untuk digunakan sebagai pertimbangan dalam kepentingan sarana air bersih dan sanitasi di pedesaan.

\section{LOKASI PENELITIAN}

Survai ini difokuskan pada dua propinsi di Sclatan dan Barat Daya dari Phnom Penh yaitu Propinsi Kompong Speu dan Propinsi Takeo. Perhatian ditujukan pada dua propinsi tersebut karena propinsi- propinsi itu tergolong miskin, bahkan Kompong Speu merupakan propinsi termiskin di Kambodia (Gambar 1 dan 2).

Pilihan lokasi yang tersebut juga didasarkan atas segi keamanan dan relatif terjangkau dari segi pelaksanaan survai yang . singkat. Oleh sebab itu pengamatan rinci selanjutnya dipusatkan di Propinsi Kompong Speu. Propinsi Kompong Speu mempunyai luas 
$7.016 \mathrm{~km} 2$ terdiri dari 8 distrik (Srok) yaitu:

1. Distrik Samrong Tong

2. Distrik Kompisei

3. Distrik Bor Seth

4. Distrik Phum Srouch

5. Distrik Odong

6. Distrik Thpong

7. Distrik Oral

8. Kota Kompong Speu

Setiap distrik (Srok) dibagi menjadi beberapa Komune (Khum) dan setiap komune terdiri dari bcberapa desa (Phum). Setiap desa (Phum) terbagai menjadi beberpa kelompok permukiman disebut Krom. Krom hampir sama seperti pedukuhan di Jawa Tengah. Jumlah Khum, Phum dan Penduduk di masing-masing distrik adalah pada Tabel 1.
Kompisei dengan pertimbangan:

a. letaknya yang relatif mudah terjangkau dan tidak jauh dari jalan negara, hingga pengaturan perlengkapan lebih mudah dan bila terjadi sesuatu, mobilitas untuk menyelamatkan diri ke Phonm Penh lcbih mudah;

b. jumlah penduduk cukup banyak hingga dapat mencerminkan kondisi daerah penelitian;

c. berdekatan dengan distrik lain yang penduduknýa juga banyak (Samrong Tong dan Bor Seth);

d. kemanan di distrik ini paling baik dan juga tidak banyak sisa ranjau yang belum dibersihkan.

Khum Vilei mempunyai penduduk sebesar 6949 jiwa yang termasuk kc dalam 1269 kepala keluarga. Desa-desa di daerah tersebut mempunyai pendu-

Tabel 1 : Kndisi Penduduk pada Masing-masing Distrik di Propinsi Kompong Speu.

\begin{tabular}{|l|rrr|rr|}
\hline Srok & $\begin{array}{r}\text { Jumlah } \\
\text { Khum }\end{array}$ & $\begin{array}{r}\text { Jumlah } \\
\text { Phum }\end{array}$ & $\begin{array}{r}\text { Jumlah } \\
\text { Krom }\end{array}$ & $\begin{array}{r}\text { Jumiah } \\
\text { Penduduk }\end{array}$ & $\begin{array}{r}\text { Jumlah } \\
\text { KK }\end{array}$ \\
\hline & 15 & 279 & 959 & 86,109 & 16,646 \\
Samrong Tong & 13 & 250 & 781 & 78,183 & 13,762 \\
Kongpisei & 15 & 218 & 1,070 & 86,673 & 16,218 \\
Bor Seth & 12 & 118 & 407 & 39,124 & 8,358 \\
Phum Srouch & 15 & 250 & 775 & 82,109 & 14,198 \\
Odong & 7 & 71 & 316 & 35,449 & 5,899 \\
Thpong & 5 & 22 & 110 & 6,949 & 1,435 \\
Oral & 5 & 56 & 216 & 26,877 & 4,789 \\
Koca Kompong Speu & 5 & & & & \\
\hline
\end{tabular}

Dan gambaran tersebut terlihat bahea kepadatan penduduk cukup rendah. Pengamatan lapangan lebih jauh dipusatkan Khum Vilei, distrik duk yang rendah, bahkan ada desa-desa yang hanya dihuni olch 50 kepala keluarga, itupun masih terbagi lagi menjadi bebcrapa gerumbul (krom). 


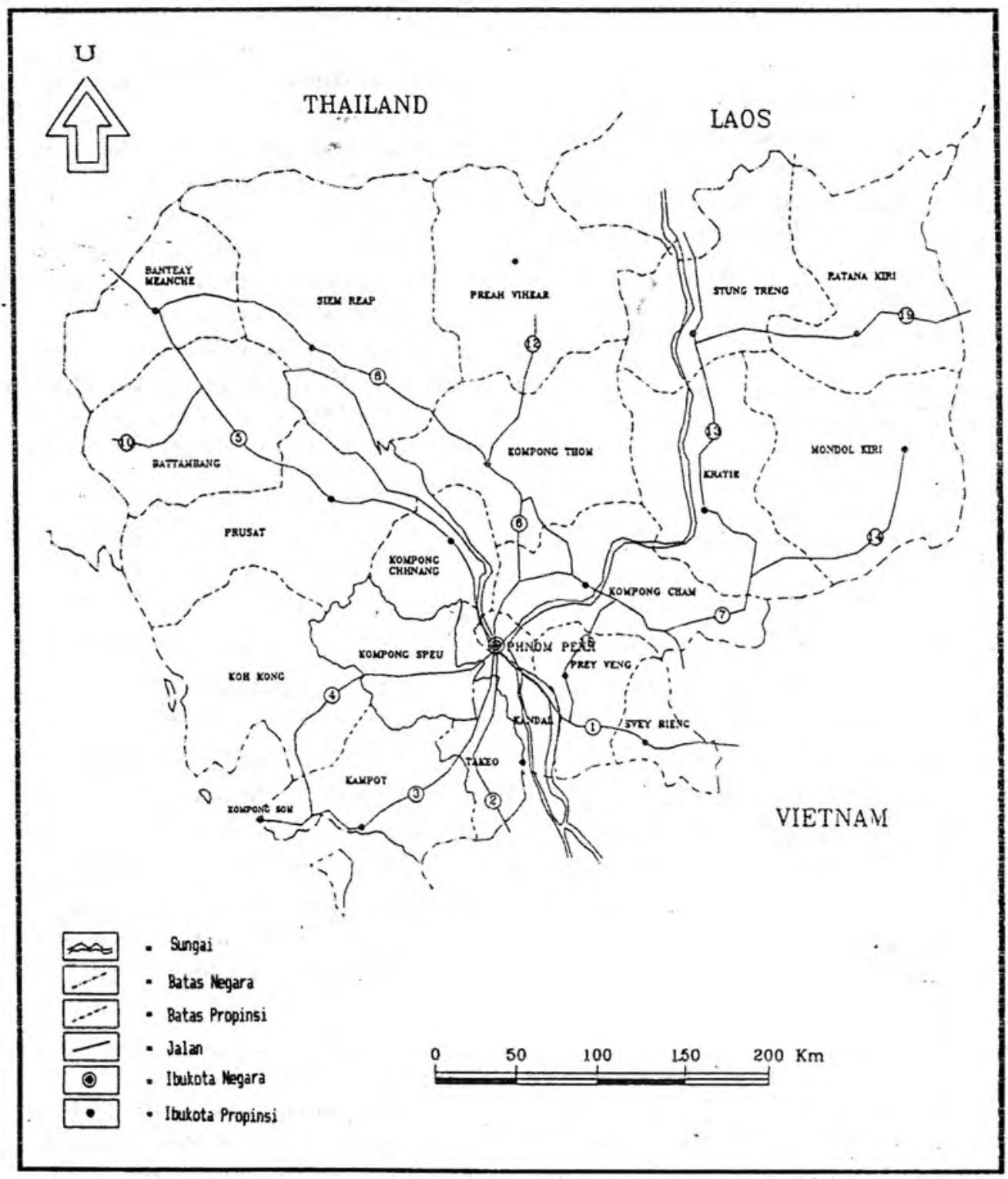

Gambar 1 Negara Kamboja 


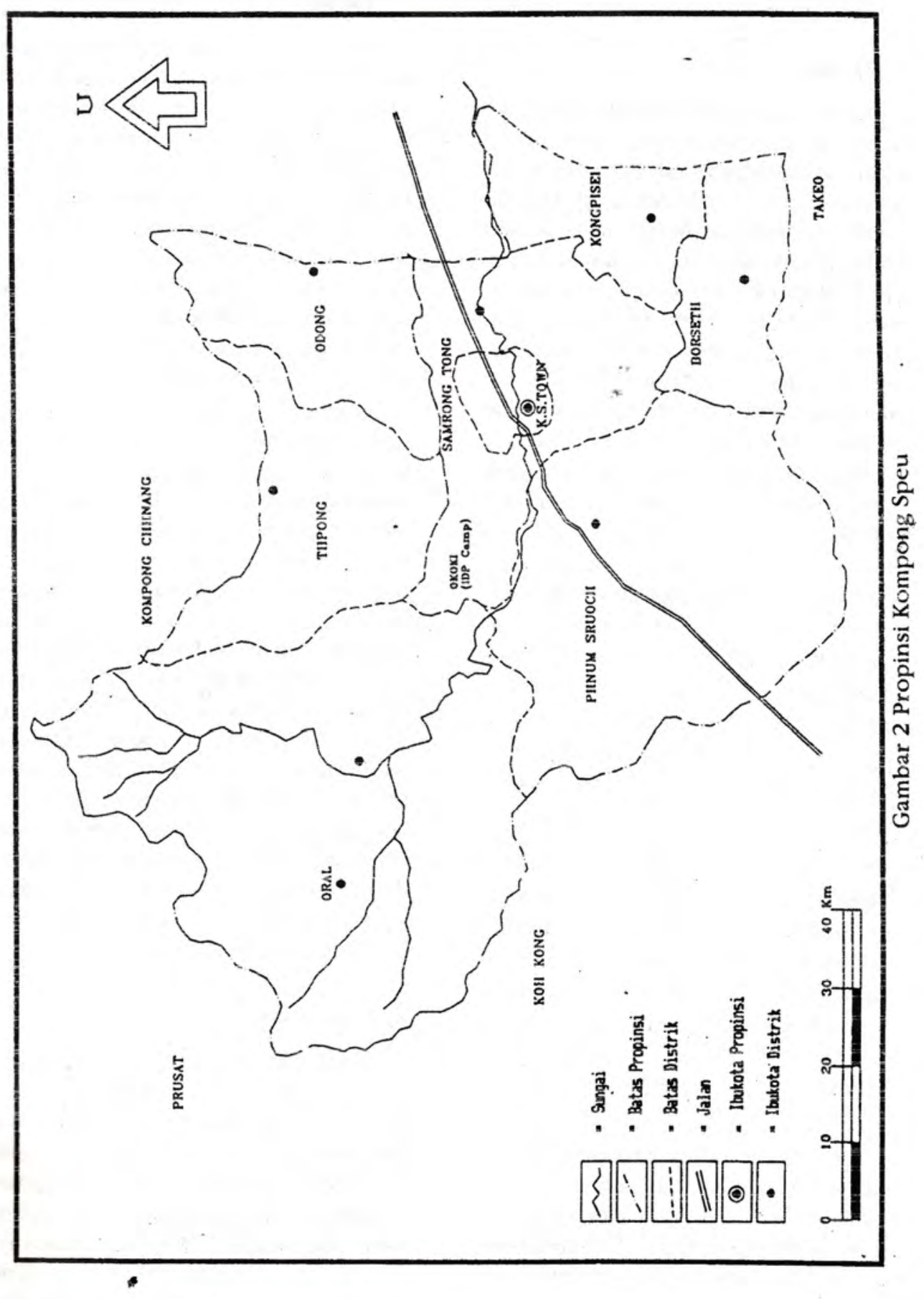

Forum Geografi No. 13 Th. VII/Desember 1993 


\section{KONDISI FISIK DAERAH PENG AMATAN}

\section{Iklim}

Dacrah penelitian yang termasuk ke dalam Propinsi Kompong Speu merupakan satu daerah endapan aluvial pada sisi kanan Sungai Mekong. Daerah ini mempunyai dua musim ialah musim basah (penghujan) dari bulan Mei sampai dengan Oktober dan musim kering dari bulan Desember sampai dengan April. Curah hujan rata-rata tahunan kira-kira $1160 \mathrm{~mm}$ (tahun 1983-1990). Gambaran distribusi hujan dari bulan ke bulan ditunjukkan pada Tabel 2 .

Tabel 2. Curah Hujan di Kompong Speu dan sekitarnya Tahun 1991 (dalam $\mathrm{mm}$ )

\begin{tabular}{lrr}
\hline Bulan & Kompong Speu & Kandal \\
\hline Januari & 0 & 0 \\
Februari & 0 & 0 \\
Maret & 0 & 0 \\
April & 86 & 41 \\
M e i & 56 & 82 \\
Juni & 178 & 193 \\
Juli & 208 & 130 \\
Agustus & 171 & 184 \\
September & 177 & 205 \\
Oktober & 166 & 158 \\
Nopember & 0 & 3 \\
Desember & 0 & 0 \\
\hline Setahun & 1050 & 996 \\
\hline
\end{tabular}

Temperatur udara rata-rata $28^{\circ} \mathrm{C}$; maksimum temperatur adalah $40^{\circ} \mathrm{C}$ terjadi pada bulan April dan temperatur minimum sebesar $19^{\circ} \mathrm{C}$. Kelembaban relatif rata-rata daerah penelitian sekitar $\mathbf{8 0 \%}$

\section{Geologi, Geromorfologi dan Tanah}

Daerah ini mempunyai batuan sedimen berupa lempung dan hasil proses sedimentasi akibat luapan Sungai Mekong dan anak-anak sungainya. Beberapa bukit kecil terdapat di daerah ini yang merupakan batuan vulkanik ande. sitik. Batuan kwarsa juga didapatkan, di beberapa tempat sudah membentuk pasir kwarsa. Sesuai dengan letaknya daerah ini membentuk suatu dataran aluvial yang mempunyai kemiringing kurang dari $3 \%$ (datar).

Banyak dijumpai rawa-rawa (ponds) yang menunjukkan daerah tersebut mempunyai drainase yang kurang baik. Air hujan tidak dapat mengalir dengan baik karena datarnya daerah itu, namun air hujan juga tidak dapat meresap ke dalam tanah dengan cepat karena kedapnya tanah dan batuan di daerah itu kedap air. Tanah di daerah ini berupa tanah aluvial yang mempunyai tekstur lempung berpasir halus. Di daerah berbukit tanahnya merupakan Laterit. Tanah aluvial tersebut bersifat asam, berwarna pucat dalam keadaan kering, sedangkan dalam keadaan basah berwarna lebih gelap dengan tekstur lekat. Selain mempunyai tekstur lempung tanah ini mempunyai permeabilitas yang rendah.

\section{Hidrologi}

Tidak terdapat data yang memadai untuk menguraikan kondisi hidrologi di daerah Komposei dan sekitarnya. Berdasarkan observasi lapangan terlihat bahwa daerah penelitian sering tergenang air di musim hujan dan mengalami kekeringan di musim kemarau. Tanah yang mempunyai tekstur lempung dengan permeabilitas rendah me- 
nycbabkan air tidak dapat meresap ke dalam tanah, dan topografi yang datar menycbabkan air sulit meninggalkan daerah itu, schingga terbentuklah ra. wa-rawa maupun genangan.

Dengan tempcratur yang relatif tinggi, (rata-rata tahunan $28^{\circ} \mathrm{C}$ ) diperkirakan evaporasi di daerah ini cukup tinggi pula. Kehilangan air terutama disebabkan oleh besarnya evaporasi permukaan, bukan oleh infiltrasi. Di daerah penelitian terdapat beberapa buah sungai yang pada akhirnya bergabung dengan Sungai Mekong. Saluran irigasi terdapat pula di daerah pengamatan, namun kondisinya jelek. Dasar saluran irigasi terletak lebih rendah daripada dasar sawah, sehingga saluran ini lebih banyak berfungsi sebagai saluran peng. atus (drainase).

\section{Hidrogeologi}

Kondisi hidrogeologi diuraikan berdasarkan pengamatan di lapangan, dengan memperhatikan kondisi geomorfologi, topografi, dan tanah daerah penelitian. Dataran aluvial lembah Sungai Mekong memungkinkan terjadinya akumulasi air termasuk air tanah di daerah sekitarnya. Endapan aluvial yang diendapkan oleh Sungai Mekong dan anak-anak sungainya memungkinkan berfungsi sebagai akifer, namun sifat tanah tidak memungkinkan air hujan meresap dengan baik. Hal terscbut memberikan indikasi bahwa potensi air tanah bebas pada unconfined aquifer terbatas.

Di daerah Kompong Speu, terdapat sebuah sumur bor dengan kedalaman mencapai $77 \mathrm{~m}$. Sumur ini menghasilkan air yang cukup baik, ditinjau dari kuantitas maupun kualitasnya. Pada kedalamanan 36 meter dari permukaan tanah sudah dijumpai air, tetapi untuk mendapatkan air dalam jumlah yang lebih besar, sumur tersebut diperdalam sampai pada kedalaman $77 \mathrm{~m}$ di bawah muka tanah.

Di perkampungan yang berjarak kurang lebih $8 \mathrm{~km}$ utara dari sumur tersebut didapatkan sebuah sumur pompa yang dibuat ileh UNICEF pada tahun 1987 dan mendapatkan air pada kedalaman $33 \mathrm{~m}$ di bawah muka tanah. Air yang dihasilkan mencapai $9001 /$ jam atau 0,25 l/detik. Air yang dihasilkan cukup baik, tak berwarna, tak berasa dan tak berbau.

Di Takeo terdapat pula sumur-sumur pompa dan sumur gali. Salah satu sumur pompa tangan dibuat pada bulan Februari 1994. Sumur ini mencapai kedalaman $27 \mathrm{~m}$ di bawah muka tanah. Material yang dijumpai pada kedalanan $33 \mathrm{~m}$ berupa pasir kwarsa halus berwarna coklat keputihan. Pasir kwarsa yang merupakan akifer pembawa air. Air yang diperoleh cukup jernih tak berasa dan tak berbau.

Pengamatan perlapisan batuan di daerah sekitarnya menunjukkan bahwa pada kedalaman sekitar 2-3 m dari muka tanah didapatkan napal dan batu lempung berlapis-lapis. Di daerah Takeo juga didapati lapisan batuan tersebut pada kedalaman yang hampir sa$\mathrm{ma}$, terlihat dari galian kolam-kolam penampung air, yang banyak dijumpai di daerah tersebut. Lapisan batuan ini merupakan lapisan kedap air yang dapat menahan air permukaan, sehingga tidak mengalami infiltrasi/perkolasi. Selain berfungsi sebagai lapisan penahan air, lapisan ini juga berfungsi sebagai batas atas akifer tertekan di daerah ini.

Berdasarkan pengamatan di Kompong Speu dan Takeo dapat diperkirakan bahwa di daerah penelitian dida- 
patkan 2 jenis akifer, yaitu unconfined dan confined aquifer, namun lapisan unconfined aquifer tidak menunjukkan potensi air yang cukup. Scbaliknya, potensi air tanah yang baik didapat dari confined aquifer yang terdapat pada kedaiaman 25 hingga 80 meter.

\section{Penggunaan Lahan}

Data jenis dan luas penggunaan lahan secara tepat tidak dapat diperoleh pada saat survei. Dalam observasi diketahui bahwa penggunaan lahan yang paling menonjol di daerah penelitian adalah sawah. Urutan kedua adalah lahan pekarangan (termasuk perumahan dan pemukiman), sedang urutan ketiga adalah lahan yang digunakan sebagai daerah perkotaan. Sawah ditanami padi yang menggantungkan air dari curah hujan; hampir tidak terlihat adanya pengaturan irigasi teknis. Di pematangpematang ditanami siwalan (sejenis palma); daun siwalan ini digunakan untuk atap rumah. Buahnya juga digunakan sebagai bahan tuak (minuman keras khas daerah).

Secara keseluruhan terlihat bahwa tutupan vegetasi di daerah ini sangat rendah. Daerah perkampungan tidak tertata rapi, tanaman yang ada tidak diatur secara baik, sehingga hanya tumbuh dengan seadanya. Banyak binatang piaraan berkeliaran tanpa dibuat kandang, termasuk lembu yang mencari makan di sawah. Oleh sebab itu pada waktu tidak ditanami padi, sawah dan tegalan digunakan sebagai ladang penggembalaan ternak. Ternak (sapi dan babi) amat penting bagi masyarakat karena disamping berfungsi untuk tambahan pendapatan khususnya sapi juga berfungsi sebagai tenaga dalam pengolaham lahan.

\section{PENYEDIAAN AIR DAN SANITASI}

Penyediaan air di dacrah perkotaan maupun dacrah pedesaan di Kompong Speu dan Takeo merupakan masalah yang rumit. Baik di daerah perkotaan maupun di pedesaan masalah penyediaan air belum tertata baik, ditinjau dari segi sistem serta kaitannya dengan kesehatan masih belum memadai. Demikian hainya dengan masalah sanitasi. Berdasarkan pengamatan lapangan di Kompisei, air untuk penyediaan air diperoleh dari tiga sumber yaitu:

\section{Air Hujan}

Air yang bersumber dari hujan diperoleh dengan cara menampung dari atas yang kemudian ditempatkan di dalam bak maupun tempayan, yang ratarata berukuran 500 hingga 1000 liter. Dengan menggunakan beberapa tempayan, maka air hujan cukup dapat diperoleh guna keperluan sehari-hari (lihat Gambar 2). Dalam satu keluarga digunakan sekitar 2 hingga 5 tempayan. Kadang-kadang dari atas ditampung dalam bak penampung air hujan (PAH) semacam ferro cement. Karena curah hujan relatif rendah dan pada bulan. bulan tertentu terdapat beberapa bulan berturut-turut tidak ada hujan, ma. ka penampung air hujan diusahakan cukup untuk cadangan bulan-bulan kcring.

\section{Air Permukaan}

Air permukaan yang bersumber dari sungai atau rawa diperoleh dari sungai atau genangan di dekat rumah tinggalnya. Air diambil dari sumbernya dengan menggunakan ember, dibawa ke rumahnya dan meyimpannya di dalam tempayan. Bentuk tempayan di daerah 
ini sangat spesifik (lihat Gambar 3).

Air yang dipcrolch dari kolam juga diperolch dengan cara yang sama. Banyak penduduk yang membuat kolah didekat rumahnya dengan bentuk persegi, dengan ukuran panjang $10 \mathrm{~m}$, lebar dalam mencapai 1 hingga $2 \mathrm{~m}$. Dasar kolam lebih sempit dibandingkan permukaannya, untuk menghindari agar tanah tidak mudah longsor (lihat Gambar 4).

Air dapat bertahan di dalam kolam dalam waktu yang lama karena infiltrasi rendah, yang disebabkan oleh lapisan kedap air pada kedalaman sekitar 2-3 $\mathrm{m}$ dari muka tanah. Keperluan mandi dan mencuci pakaian dilakukan di tempat sumber air (Gambar 5).

\section{Air Tanah}

Air tanah diperoleh dengan cara membuat sumur gali maupun sumur pompa tangan. Sumur-sumur jumlahnya belum memadai, dan kebanyakan merupakan bantuan dari UNICEF atau pihak luar, dan jarang yang dibuat atas prakarsa sendiri. Dibandingkan dengan luas daerah serta jumlah penduduknya, jumlah sumur gali terbuka dengan cincin, sangat kecil dan pada umumnya sumur ini mempunyai kedalaman air sekitar 3 meter atau lebih dari muka tanah dengan dan diameter sekitar 80 $120 \mathrm{~cm}$. Sumur pompa tangan yang ada di daerah penelitian dapat dilihat pada (gambar 6).

Berdasarkan pengamatan di lapangan, dari ketiga jenis sumber air di atas sumber air yang paling banyak digunakan adalah sumber air yang kedua (sungai, rawa atau kolam). Dilihat dari segi kualitasnya dan keamanannya yang berkaitan dengan kesehatan, maka sumber air yang kedua justru paling memprihatinkan. Air sungai pada musim kemarau amat kotor karena tidak terjadi aliran sama sekali dan hanya sekedar berfungsi sebagai genangan, sedangkan air kolam lebih keruh lagi, karena ari hujan yang tertampung sudah tercampur suspensi tanah lempung yang dilewatinya.

Di dalam kolam inilah dilakukan kegiatan mereka mandi, cuci, memandikan sapi, babi dan sebagainya.

Sulit untuk merubah kebiasaan penduduk dalam penyediaan air. Walaupun telah dibuatkan sumur-sumur supaya penduduk menggunakan air yang lebih baik kualitasnya namun masih juga menggunakan air kolam untuk keperluannya, karena air kolam lebih mudah didapatkan. Penggunaan air tanah masih sangat terbatas karena jumlah sarana sumur yang masih jauh dari memadai dan lokasinya yang masih jauh dari permukiman. Disamping itu masalah kebiasaan juga merupakan salah satu hambatan, sehingga disamping bantuan dalam pengadaan sarana sumur yang lebih memadai, usaha penyuluhan untuk merubah kebiasaan masyarakat juga dipcrlukan. Hal ini berkaitan erat dengan kondisi sosial ekonomi penduduk setempat.

Dengan kondisi tersebut, agak sulit untuk mengetahui besarnya pengguna. an air setiap keluarga maupun setiap orang. Dari pengamatan, jumlah penggunaan air untuk keperluan domestik berkisar dari 40 hingga 70 liter per orang per hari.

Kondisi sanitasi sangat menyedihkan. Binatang piaraan banyak berkeliaran dan membuang kotoran sembarangan, sehingga bila hujan turun maka kumpulan tinja binatang ada scbagian terbawa masuk ke dalam kolam, sehingga air kolam praktis terkontami- 


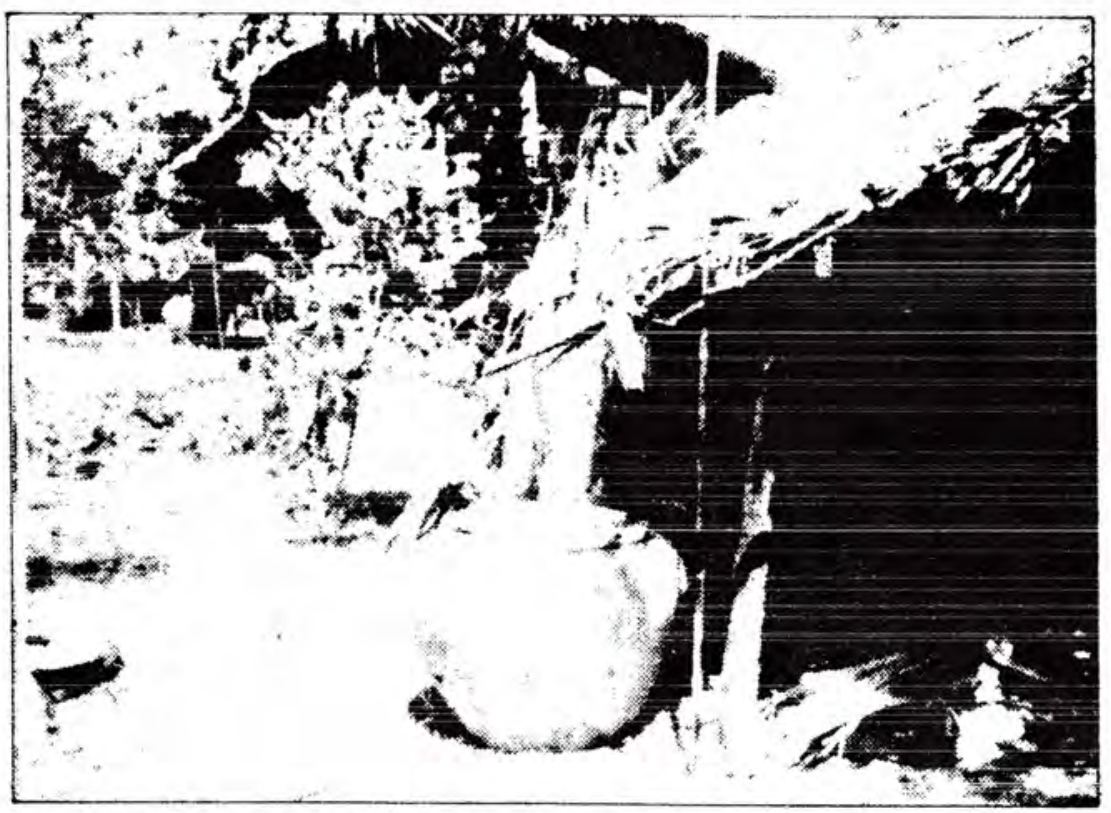

Gambar 3. Tempayan Penyimpan Air

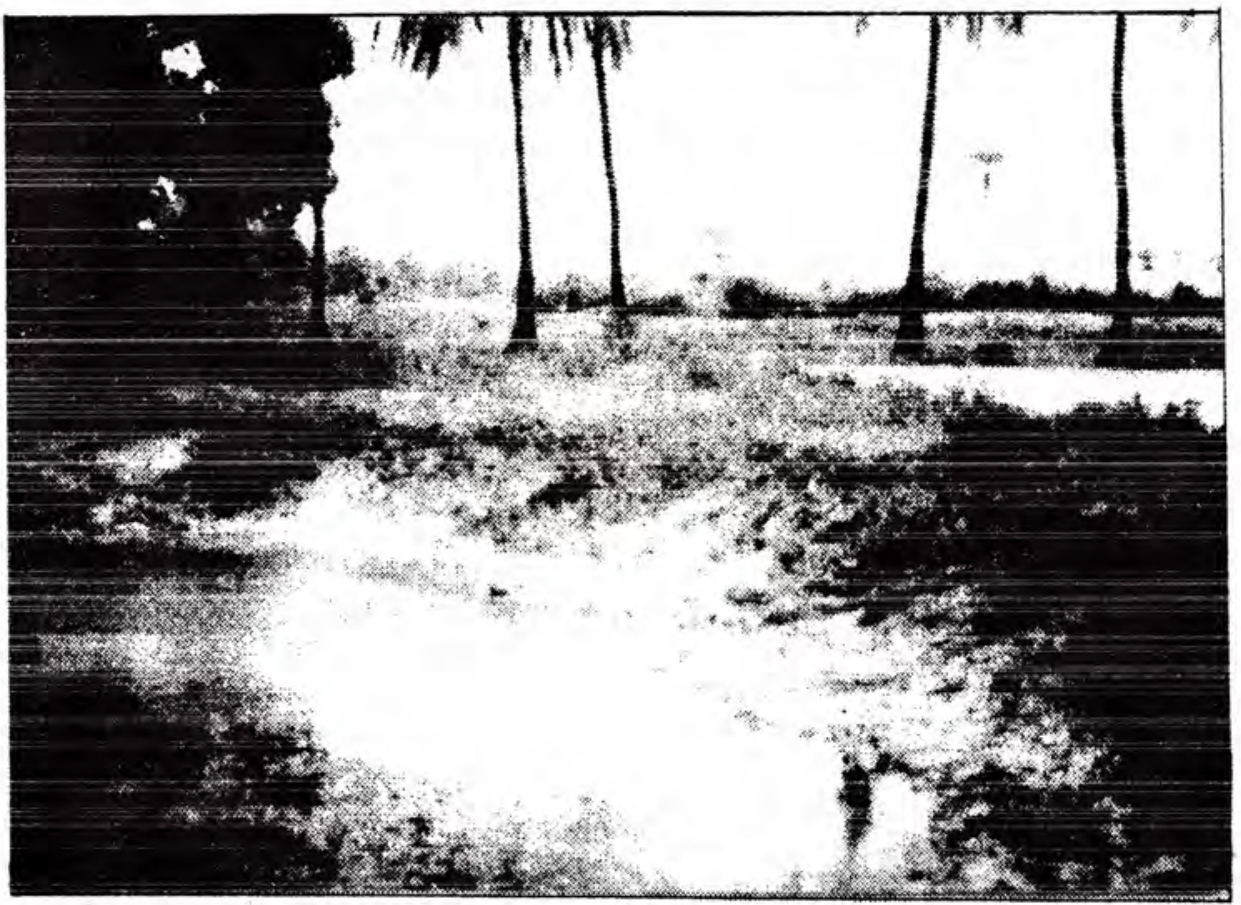

Gb. 4 Kolam Untuk Sumber Air Domestik 


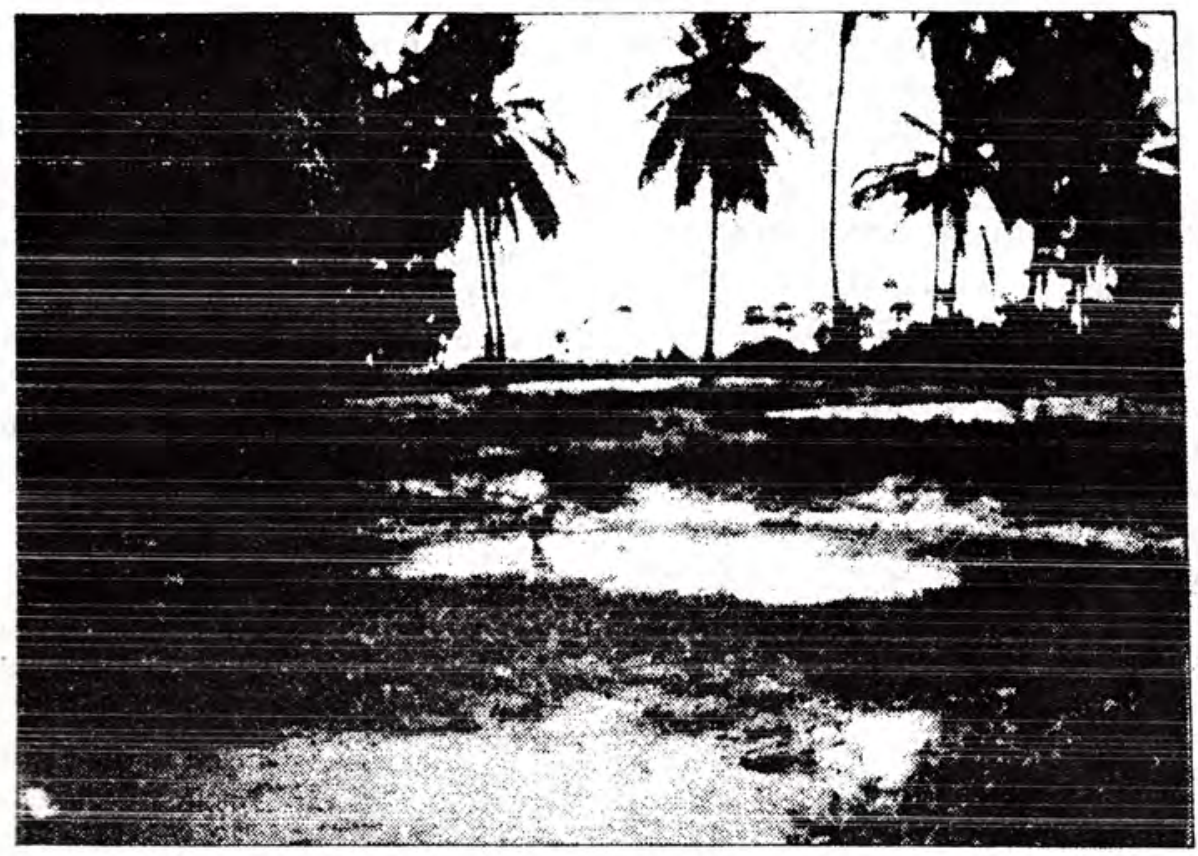

Gambar 5. Menggunakan Air Kolam Langsung

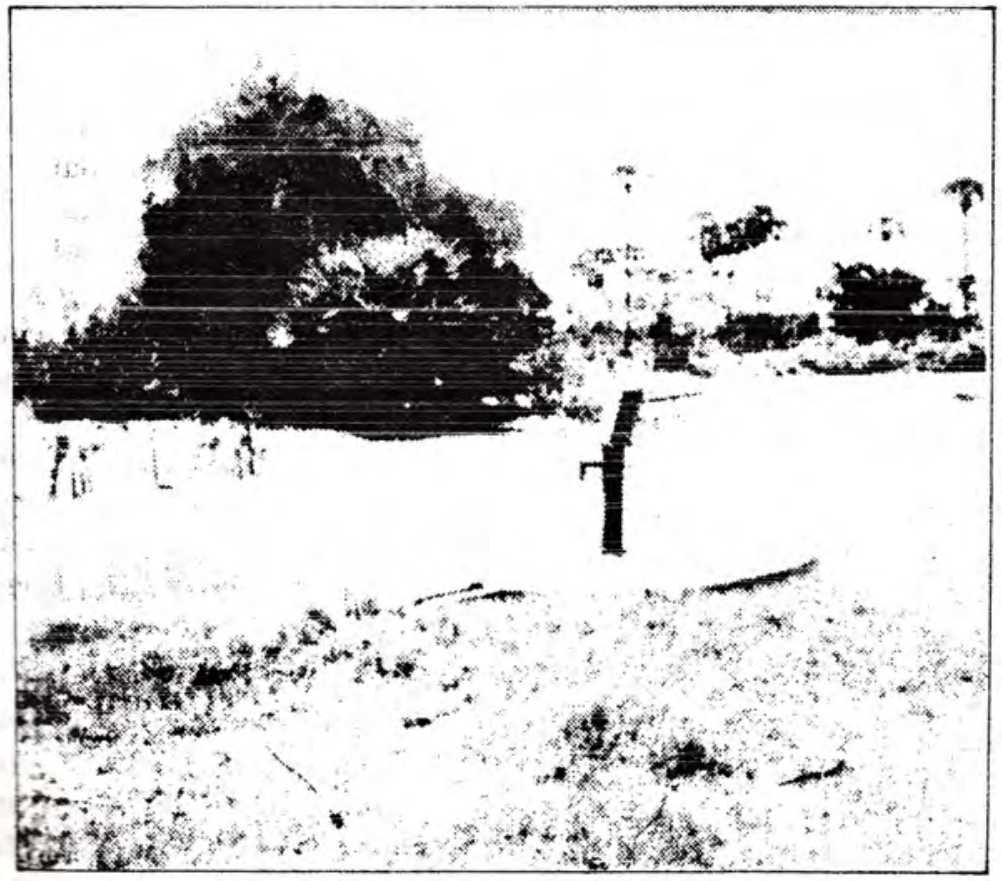

Gb. 6 Pompa Tangan Untuk Menurap Air Tanah 
nasi. Pembuangan limbah domestik dilakukan di sembarang tempat sekitar rumahnya, tanpa terkontrol.

\section{ASPEK SOSIAL DAN KAITANNYA DENGAN SANITASI}

Gambran rinci tentang kondisi sosial masyarakat di lokasi sulit untuk diketahui dalam waktu singkat. Uraian di bawah ini sekedar berdasarkan impresi selama kunjungan ke lapangan, wawancara dengan masyarakat dan informasi tidak langsung dari berbagai pihak. Uraian singkat ini merupakan gambar umum yang ada, tetapi dapat digunakan sebagai masukan bagi setiap perencana program bantuan di Kambodia, khususnya program yang akan melibatkan masyarakat setempat, termasuk penyediaan air bersih.

Dari observasi lapangan dan diskusi dengan masyarakat pedesaan, diperoleh kesan bahwa rasa putus asa masyarakat pedesaan merupakan masalah yang serius. Hal ini dapat dimaklumi karena, siapapun yang hidup dalam situasi perang selama lebih dari 30 tahun, harus mengungsi dari satu tempat ke tempat lain, banyak kehilangan anggota keluarga karena terbunuh, tentu akan kehilangan rasa percaya diri. Tujuan hidup hanya sekedar mencari selamat dalam menghabiskan sisa hidupnya. Akibat dari kondisi di atas program-program yang sifatnya abstrak sulit dimengerti, misalnya program pendidikan, penyelamatan lingkungan dan lain sebagainya sulit untuk dihayati, sungguhpun amat penting untuk hari depannya. Gejala umum yang mudah terlihat adalah sikap apatis dan lebih banyak menunggu. Gairah untuk mengambil inisiatip amat terbatas; semua masukan dari pihak manapun akan diterima dengan rasa was-was.

Usaha-usaha untuk membantu masyarakat agar rasa percaya diri timbul kembali, merupakan suatu usaha yang sangat diperlukan. Bagi penduduk pedesaan proses pengembalian rasa percaya diri bukan dicapai melalui pendekatan yang teoritis, tetapi justru lewat program kecil yang nyata.

Dengan kondisi perang bertahuntahun dan hidup yang harus mengung. si dari suatu tempat ke tempat lain penduduk sudah terbiasa hidup dari belas kasihan pihak lain, seperti negara lain, organisasi donor, dan lain sebagainya. Di tempat pengungsian, kebutuhan makan, pakaian dan juga uang tclah disediakan dan praktis penduduk hanya menerima saja. Jumlah pemberian tersebut mungkin tidak memadai, tetapi paling tidak selama bertahun-tahun tclah dinikmatinya. Sebagai akibatnya kegiatan pembangunan apapun (lebih-lebih dari bantuan luar) dianggap sebagai pemberian cuma-cuma.

Kehidupan masyarakat pedesan sungguh amat sulit. Fasilitas yang sebenarnya amat biasa, sudah dianggap sebagai suatu kemewahan. Situasi yang amat kontras terjadi pada waktu pasukan PBB ditempatkan di Kambodia. Di satu sisi pasukan PBB membelanjakan uangnya yang cukup berlimpah, hingga dapat menaikkan kehidupan ekonomi setempat, di sisi lain menimbulkan anggapan bahwa semua orang asing adalah jutawan, sehingga kesemuanya berakhir pada suatu kesenjangan dan rasa apatis.

Di Indonesia, kegiatan bersama yang dilakukan oleh masyarakat selalu memperoleh penilaian positif, karena menunjukkan kekompakan dan rasa gotong royong bersama dalam jumlah besar, bahkan untuk penyuluhan saja 
tidak mungkin penduduk dikumpulkan dalam jumlah besar.

Untuk berbagai program pemba. ngunan (pembuatan sarana air bersih, pertanian) maksimum peran serta yang dimungkinkan adalah peran serta dalam kelompok kecil. Misalnya 5 keluarga bekerja bersama dimana mereka dapat saling percaya. Hal tersebut memang kurang efisien, tetapi tidak ada alternatif lain. Oleh sebab ini perbaikan sarana air bersih dan sanitasi tidak dapat dilakukan dengan mudah, walaupun hal ini sangat diperlukan. Peran serta masyarakat pedesaan Kamboja harus diperhatikan, dan hal ini hanya dapat dicapai dengan pendekatan per. suasif, dengan contoh konkrit. Penyuluhan tentang kesehatan lingkungan diperlukan dan bila diperlukan program ini harus dilakukan dari rumah ke rumah.

\section{KESIMPULAN}

1. Masalah air bersih dan sanitasi dihadapi oleh negara berkembang negara cukup rumit. Lebih-lebih negara-negara yang dilanda perang yang berkepanjangan seperti Kambodja.
Sumber air alami yang merupakan sumber air bersih, dari segi kualitasnya tidak dapat dipcrtanggungjawabkan, tetapi hal ini tidak dapat dihindari oleh penduduk setempat, sehingga penduduk memanfaatkan air seadanya.

2. Teknik penyediaan air yang dilakukan di daerah pedesaan Kambodja sangat sederhana dan lebih banyak menggantungkan kepada kondisi air alami. Teknik-teknik sederhana dalam pemanfaatan sumber air bersih belum dikenal dengan baik. Pengetahuan dan dana menjadi kendala utama dalam pemanfaatan air tersebut.

3. Kctcrbatasan pengetahuan dan dampak perang yang berkepanjang. an merupakan penyebab utama sulitnya merubah kebiasaan penduduk untuk menggunakan air yang lebih baik dari air permukaan ke air tanah, demikian pula untuk memperbaiki sanitasi lingkungan.

4. Dalam penyediaan sarana air bersih dan sanitasi harus memperhatikan permasalahan masyarakat, melalui program yang nyata yang dapat segera terlihat hasilnya.

\section{REFERENSI}

Anton Sudjarwo, Adik Bantarso dan Sudarmadji, 1994. Laporan Misi dalam Rangka Bantuan Pemerintah Republik Indonesia untuk Kambodja, Yayasan Dian Desa, Yogyakarta.

Japan International Cooperation Agency, 1992. Project Formulation Study on Resetlement of Refugees in Cambodia, JICA.

Cambodia-IRRI Rice Project, 1992. Annual Reseach Report, 1991. Cambodia-IRRI Rice Project, Phnom Penh.

McClelland, M.I, 1975. Individual Onsite Wastewater Systems. Ann Arbor Science, Michigan.

Davis, S.N. and DeWiest, R.J.M., 1966. Hydrogeology. John Wiley and Sons, London. Gregory, K.J. apd Walling, D.E., 1976. Drainage Basin Form and Process, A Geomorphological Apparoach. Edward Arnold, London. 